\title{
STRENGTHENING THE COMPENSATORY BASICS FOR VIOLATED SUBJECTIVE CIVIL RIGHTS PROTECTION IN THE EUROPEAN UNION MEMBER STATES AND THE RUSSIAN FEDERATION
}

\author{
Sergey V. Romanchuk * \\ Svetlana S. Racheva ${ }^{* *}$
}

\begin{abstract}
The article tackles a problem of disputable issues coming alongside the implementation of public interests for the protection of violated private property rights in the European Union member states and the Russian Federation in regard of the possibility to collect additional (compensatory) or punitive amounts above the prescribed. The article provides an overview of various approaches to define the notion "the right to judicial protection" and the "protection method" in European and Russian legal doctrines. The authors highlight controversial issues of imposing additional (compensatory) payments in Great Britain and Germany as a vivid example of various legal systems in action. The purpose of the article is to substantiate the global task - to develop a mechanism of additional compensation for violated rights in the legislation of the EU, EU member states and the Russian Federation with the focus on proprietary rights.
\end{abstract}

\section{INTRODUCTION}

In pursuance of the President Decree No. 1108 of July 18, 2008 (as amended on July 29, 2014) "On the Improvement of the Civil Code of the Russian Feder-

\footnotetext{
Associate Professor at Civil Law and Procedure Department, Institute of State and Law, Tyumen State University; ser-romanchuk@mail.ru.

** Associate Professor of Foreign Languages and Intercultural Professional Communication at Department for Law and Economics, Institute of State and Law, Tyumen State University; racheva71@mail.ru.
} 
ation,"1 a Concept of Civil Legislation Development has been worked out and significant changes to the Civil Code of the Russian Federation were made. One of the primary goals of the reforms reflected in President Decree No. 1108 is the necessity to bring the provisions of the Civil Code of the Russian Federation closer to the rules of legal regulation of relevant relations in the EU law.

This fact substantiates the necessity to study the EU and its member states legal regulations, as well as the doctrinal provisions of Civil law, based on different legal traditions. The need to strengthen market foundations in the context of globalization and internationalization of law creates a stable trend towards the rapprochement of continental and Anglo-Saxon legal systems, which used to be antagonistic.

Analyzing the issues of violated subjective civil rights protection (private rights); the authors stick to the supposition that there is always a public interest in the protection of private right. It manifests itself in the preventive function of law, expressed in the need to reduce the level of rights violations and the stabilization of civil turnover, as well as to ensure effective and entire consideration of the case from the proceedings objectives' point of view.

Ineffective judicial proceedings, excessively overwhelmed with claims, often become one of the incentives to violate the rights by a person, who foresees and calculates his own, and others' property and time costs. According to statistics provided by the Judicial Department of the Supreme Court of the Russian Federation $^{2}$ in 2016, 2323 applications were filed to accelerate the consideration of the case in civil proceedings (2475 applications in 2015, 2024 applications in 2014); 587 applications for awarding the compensation for violation of the right to legal proceedings within a reasonable period of time (444 applications in 2015, 625 applications in 2014). ${ }^{3}$

The adoption of the Federal Law "On Compensation for violation of the right to legal proceedings within a reasonable period of time or the right to enforce a judicial act within a reasonable time" in 2010 testifies a public interest in the effective (timely) protection of violated subjective private rights through adversary justice, based on a detailed comprehensive consideration and resolution of the dispute.

1 Decree of the President of the Russian Federation of July 18, 2008, No. 1108 (amended on July 29, 2014) "On the Improvement of the Civil Code of the Russian Federation", Collection of Legislation of the Russian Federation. № 29 (Part 1), art. 3482. 2008

2 http://www.cdep.ru/index.php?id=79\&item $=3832$

3 Federal Law No. 68-FL of 30 April 2010 "On Compensation for Violation of the Right to Proceed in Due Process within a Reasonable Time or the Right to Enforce a Judicial Act within a Reasonable Time" (as amended on 19.12.2016), Collection of Legislation of the Russian Federation. № 18. Art. 2144. 2010 
The authors believe that, one of the main tasks of the judicial protection mechanism is to create conditions for reducing the number of violations, strengthening the level of legal awareness and legal culture, as well as conscientiousness of civil turnover participants. Violation of rights or the possibility of violation should become both unacceptable and unprofitable for any participant of civil turnover, regardless of its property status.

\section{COLLISIONS IN UNDERSTANDING THE NOTIONS "THE RIGHT TO JUDICIAL PROTECTION" AND "THE METHOD OF VIOLATED SUBJECTIVE CIVIL RIGHTS PROTECTION"}

Evidently, there is no unified concept of "protection of civil rights" in the Russian civil law theory. Some scientists tend to consider "civil rights" as procedural law enforcement activities exercised exclusively by the authorized state bodies in the frame of legal relations. N. T. Arapov is sure that "the protection" should be comprehended as statutory procedural activities of a court or other judicial body to hear and resolve disputes on law and other legal issues. ${ }^{4}$

The reasoning of other scientists is based on the idea that the right to protection is an element of legal capacity (legal personality). A. Ya. Kurbatov argues that legal regulation is carried out in two ways: through a legal relationship by establishing mutual subjective rights and obligations of the parties in a particular legal relationship, when it occurs; as well as beyond legal relationship through the possibility to enter into a specific legal relationship and thus fulfill their interests. ${ }^{5}$ Another opinion is to consider the right to judicial protection a part of the powers of the subjective civil right $^{6}$, or of the subjective civil right itself to protect which, the claim is directed to.

\footnotetext{
4 Arapov, N.T. Problems of the Theory and Practice of Justice in Civil Cases, Leningrad: Leningrad University Press, 1984, p. 65

5 Kurbatov, A.Ya. Problems of the application of legislation on the protection of consumer rights in the banking sector, created by judicial-arbitration practice. Entrepreneurship. Application Business and Law in Russia and Abroad. Vol. 3. pp. 36 - 39, 2013

6 Romanchuk, S.V. Traditions and innovations in determining the right to judicial protection of subjective civil rights and legally protected interests. Development of world justice in modern conditions: problems and prospects, dedicated to the 70th anniversary of the formation of the judicial system of the Tyumen region. Proceedings of the Conference of Justices of the Peace in the Tyumen region. - Tyumen: Tyumen Regional Court, pp. 29 - 31. 2014
} 
The European legal doctrine also lacks the consensus on determining the concept of "protection of civil rights". In the doctrine of German law, the right to sue has been for a long time associated with the subjective civil law, to protect which the claim is directed ${ }^{7}$. The right to sue was considered a subjective civil right to react against inconsistent will. In 1883, a German jurist J.C. Hasse defined the right to sue as the right to demand the will of the state vie the court. ${ }^{8}$ The idea of a public right of action (right to claim) was introduced by Professor Vahom (1889). ${ }^{9}$ This theory is called the "theory of public legal claims to protect the right" (Rectsschutzanspruch). At the same time, there were other opinions on this issue in the German procedural theory. A well-known legal procedure expert $H$. Degenkolb ${ }^{10}$ proposed the theory of abstract right to sue. The essence of the theory lied in fact that a right to sue is aimed at a court to make a judicial decision on a suit in general, but not specifically in favor of the plaintiff or the defendant. Modern German procedure theory of right to sue is described as the quintessence of two theories. On the one hand, it is the claiming to a court for the search of protection, on the other hand it is a claim against the defendant. ${ }^{11}$

The European legal doctrine perceives the concept of the notions "method of violated right protection" and "claim" as equal and mostly identical. Russian Civil law traditionally reckons the concept of "method of violated right protection" as a substantive right.

Universally recognized meaning of "the method of violated right protection" is a complex of fixed or sanctioned by the legislation set of material and legal measures of a compulsory nature, through which the elimination of law violations, the right restoration and (or) compensation for losses caused by a violation of law can be carried out.

Sharing a critical attitude toward the generally accepted approach, we support the opinion of P. P. Zgonnikov, who highlighted the need for a comprehensive study of the method of protection: on the one hand, the goals, subjects and object, types, bases, stages, principles, legal means, methods and forms of

\footnotetext{
7 Kroll, Wilhelm. Klage und Einrede nach Deutschem Recht: auf Grundlage der Reichsgesetze unter Berucksichtingung des gemeinen Rechtes und der wichtigsten Partikularrechte dargestellt. Berlin, 1884, p. 25

8 Hasse, J.C. Ueber das Wesen der action, Reinisches Museum fur Jurisprudenz. Bd. 1833

9 Wach, Adolf. Handbuch des deutschen Civil prozessrecht. Leipzig, Verlag von Dunkers \&Humbolt.1885, Bd. I, p. 19

10 Degenkolb, Heinrich. Einlassungszwang und Urteilsnorm. Leipzig, 1879, Beitrage zum Zivilprozess. Leipzig. 1905, p. 14

11 F.K. v. Savigny. System des heutigen römischen Rechts. Berlin, Veit und comp.1841, Bd. V, pp. $4-5$
} 
protection, and on the other hand - the ratio of protection measures and tort liability, regulatory and protective legal relations, law enforcement. ${ }^{12}$

Perception of the method of violated subjective civil rights and legally protected interests as a substantive phenomenon ${ }^{13}$ explains the focus of jurists mainly on the consideration of the material and legal elements of a protective legal relationship. In this regard, T.E. Abova and V.V. Vitryansky distinguish among the features of protection method the material nature, the subjective composition of right violators, the purposes of protection, the subjects of the appropriate method application and the grounds for that. Approach of this type focuses on the main purpose of the protection method - restoration of a violated right or elimination of the threat of its violation. We join the scientists promoting a multi-purpose approach to the notion "method of protection". ${ }^{14}$

Application of this approach to the definition of the term "method of protection" will allow, on the one hand, to take into account a complex nature of protective purpose of legal relationship and, on the other hand, the goals of judicial procedure.

Article 2 of the Civil Procedure Code of the Russian Federation states the following objectives of civil judicial proceeding: a correct and timely hearing and adjudication of civil cases aimed to protect violated or challenged rights, consolidation of legality and strengthening of law and order, prevention of offences, promotion of respect for the law and justice. ${ }^{15}$

Article 2 of the Arbitration Procedure Code consolidates 6 objectives of arbitration judicial proceeding: protection of violated or challenged rights and legitimate interests, ensuring the accessibility of justice in the field of entrepreneurial and other economic activities, timely, fair public trial by an independent and impartial court, strengthening the rule of law and preventing offenses, promoting respect for the law and court; assistance in establishing and development of partnership business relations, formation of the customs and business turnover ethics. ${ }^{16}$

12 Zgonnikov, P.P. On some topical issues of civil rights protection, Russian Justice. 2016. № 4. pp. $9-12$

13 Braginsky, M.I., Vitryansky, V.V. Contract Law. Book. The first. General Provisions. 3rd ed. M.: Statute. 2001, p. 776; Abova, T.E. Protection of Economic Rights of Enterprises and Production Associations: M., 1985, pp. 104 - 105

14 Kravchenko. A.A. On the issue of the concept of a method of protecting civil rights, Advocate. 2014. Vol. 7, pp. $22-30$

15 Civil Procedure Code of the Russian Federation No. 138- $\$ 3$ of 14.11.2002 (as amended on 03.07.2016), Meeting of the legislation of the Russian Federation. № 46. Art. 4532.2002

16 Arbitration Procedure Code of the Russian Federation of July 24, 2002 N 95-FZ (as amended on June 23, 2016), Collected Legislation of the Russian Federation. № 30. Art. 3012. 2002 
Article 3 of the Administrative Procedure Code of the RF presents 3 objectives of administrative judicial proceeding: ensuring the access to justice; protection of the violated or contested rights, freedoms and legitimate interests of the citizens, rights and legitimate interests of organizations, correct and timely consideration and resolution of the administrative cases; strengthening the rule of law and preventing violations in the field of administrative and other public relations. ${ }^{17}$

Notably, a preventive purpose of judicial procedure is soundly presented in the list of judicial proceeding's objectives. Indeed, this function is intrinsic to the European Union and the EU member states judicial systems. ${ }^{18}$ The authors believe that a preventive purpose should be included in a complex purpose of protection method or lawsuit implementation. In terms of the judicial proceeding objectives, protection in a protective legal relationship is the restoration of violated right or elimination of threat of its violation, as well as ensuring proper protection of the violated right via effective (correct, timely, accessible) judicial proceedings; provision of conditions for reducing the number and preventing violations, strengthening the rule of law; promotion of respect to the law, the court and the ethics of business turnover.

In this sense, it is crucial to strengthen the compensatory principle in the implementation of protection methods for violated subjective civil rights and legal interests, protected by the state. This issue is of a paramount importance for the implementation of proprietary and legal methods of protection, where the restoration of right is exclusively of a "reverse" nature to the legal relationship before the violation of law. At that, the legal regulation of proprietary legal protection methods does not vest a person with similar number of methods of ensuring and liability measures that are intrinsic for obligatory legal relations.

\section{METHODS OF VIOLATED PROPRIETARY RIGHTS PROTECTION}

The specific feature of a property relationship is its absolute nature. Violation of the subjective proprietary right occurs in creating obstacles for proprietary rights owner to exercise his powers, at that, the nature of the offender's actions

\footnotetext{
17 Administrative Procedure Code of the Russian Federation of 08.03.2015 No. 21-Fl (as amended on 03.07.2016), Collection of Legislation of the Russian Federation. № 10. Art. 1391. 2015

18 Treaty Establishing the European Economic Community and related instruments, Rome, March 25, 1957; European Convention for the Protection of Human Rights and Fundamental Freedoms, Rome, November 4, 1950; Code de procédure civile (France), 1975; Code of Civil Procedure (Germany) as promulgated on 5 December 2005 (Bundesgesetzblatt (BGBl) e t.c.
} 
is undue. At the same time, the demand and the measure of responsibility are often identical and lead to a defect in the compensatory and preventive functions of the proprietary and legal method of violated subjective proprietary right protecting.

It should also be accepted that there is still no sufficient clarity in the theory of civil law regarding the legal nature and content of the mechanism for judicial protection of property rights. ${ }^{19}$

The existing legal systems that have adopted the reception of Roman law have no definition of property right. Thus, the Civil Code of France defines property as the right to use and dispose of things in the most absolute way, so that the use is not one that is prohibited by laws or regulations (Article 544). In the German Civil Code, the property right is disclosed through the powers of the owner of the thing, which can, if the law or the rights of third parties do not hamper it, dispose the thing at its discretion and eliminate any interference (paragraph 903). Similarly, the right of ownership is formulated in paragraph 641 of the Swiss Civil Code.

In civil codes based on common law (otherwise called the Anglo-American legal system), a legal definition of the right of ownership is given vie certain characteristics of the things ownership or by enumerating the powers of the owner: ownership of the thing is the right of one or more persons to own or use it, removing others from it (paragraph 654 of the Civil Code of the State of California, USA).

In the Civil law of the countries that traditionally adhere to the continental system of law, there are various definitions of the vindication claim. Thus, in the Civil Code of France, vindication is defined as: "he who has lost or stolen a thing can claim it back within three years, starting from the day of loss or theft, from the one in whose hands he finds it: but this one the latter has the right of counter claim against the one who he received it from (Art.2279)". In the Swiss Civil code, the concept of vindication is given as the right of the possessor of a thing to reclaim it from anyone who holds it and to reflect any unlawful influence (Paragraph 641). The German Civil Code has the most capacious and concise definition of vindication claim: "the owner can demand a thing from the possessor of the issue" (Paragraph 985). In recent civil codifications, which perceived to some extent the reception of Roman law, the limitations of vindication became the rule. According to the Code of Napoleon, the owner whose thing is stolen or lost can claim it back from any person

19 Semenov, V.V. Vindication: theory and jurisprudence, Russian Justice. Vol. 2. pp. 8 - 10. 2016; Radaeva, O.I. Problems of judicial protection of property rights and the right of common ownership, The Russian judge. Vol.1. p. 20. 2013, p. 20 
possessing it, but only within three years (Paragraph 2279). Notably, this rule was established for movable things. From the contents of the Swiss Civil Code, it is obvious that the owner of movable property has no right to demand it from the person to whom he has transferred the property at his own will based on a contract (agreement).

An Italian professor Ugo Mattei in his book "Basic principles of property law: A comparative legal and economic introduction", thoroughly examines the main principles of property rights in Europe. ${ }^{20}$

Regarding a broad nature of the negatory action as a model of property protection in the countries of the Roman legal tradition, the clearest and simplest provision can be found in German law. In accordance with paragraph 1004 of the German Civil Code, "if ownership is disturbed than by dispossession, or refusal of restitution, the owner may obtain against the one who bothers his enjoyment the removal of the interference. If future prejudices are to be feared, the owner may obtain an injunction against their occurrence".

The Italian law, despite the wording used in Article 949 (and by correlating Article 1079) of the Civil Code, evidences a broad nature of this action in order to offer an effective remedy against all possible types of property rights infringement.

The following typology of remedies is based on the civil concept of "negatory action". Firstly, the owner is protected not only against actual damage, but also against the risk of possible losses. It is enough, to fear the prejudice to the property rights in order to claim for a remedy. Such protection is provided through Civil law through a number of different special provisions; some of them are of Roman origin. A negatory action, however, can be considered a synthesis of such provisions since it protects the property right against any type of possible risk that may affect the value of the property. Included in the negatory action is the declaratory lawsuit sent to the court to obtain a declaration of the plaintiff's ownership. Such a judicial statement, on the frontiers of the property right, should be final, valid globally, and aimed at avoiding the prejudices that may be associated with an unclear boundary between proprietary relationships. The clarity and certainty of property rights is a value that this claim aims to protect.

In various legal civil law tradition systems, this function of the negatory action is accompanied by other types of special actions aimed at clarifying the physical boundaries of the property. A nugatory action also includes a judicial in-

20 Mattei, Ugo. Basic principles of property law: A comparative Legal and Economic Introduction. By Greenwood Press. 2000, pp. $186-187$ 
junction against continuing prejudice to the property right. Such assistance can be obtained against any kind of violation, the effect of which is continuous. Vindication and negatory action so far have not lost the value of independent civil-law institutions. Accelerating rates of property turnover often lead to disputes, for the solution of which the owners resort to vindication and negatory actions. ${ }^{21}$

It is obvious, that traditional three types of claims petitory, vindictive and negatory only provide the restoration of violated proprietary rights, but do not target one of the main tasks of legal proceedings - to prevent from violations of the law and the stability of civil turnover. The empowered person is in a "weak position", as he himself should prove the guilt of the offender and the wrongfulness of the act, while receiving what is rightfully his own. The law violator does not bear any additional property losses except those that ensure the commission of the necessary actions to restore the right of action. In this regard, he violates the law, without any fear of additional negative consequences. From this point of view, the experience of legal regulation of punitive damages in the countries of Anglo-Saxon and continental systems of law is of great interest.

\section{PUNITIVE DAMAGES IN COMMON LAW AND CIVIL LAW COUNTRIES}

In the countries of the Anglo-Saxon legal family the charge of punitive damages in tort cases is a widespread practice. In essence, it is the amount of money awarded to the plaintiff in excess to the compensation of the caused harm, which is intended to punish the defendant for his especially outrageous behavior. Russian law, in general, permits the possibility of awarding the compensation above the inflicted harm. ${ }^{22}$ However, so far, no law explicitly provides for it. There is a similar practice in the European Union countries.

Tort law of European states and the European Union implements the principle of full compensation for harm. It means that the inflicted harm should be estimated in monetary terms, and the offender should pay this amount to the victim.

Punitive damages in the common - law countries are the amounts of money awarded in tort cases to the victim in excess of the compensation for harm (i.e. above the "compensatory damages"). The tortfeasor can be compelled to pay

\footnotetext{
${ }^{21}$ Morgunov, S.V. Vindication in civil law. Theory. Problems. Practice. Moscow: Statute, 2006, $301 \mathrm{p}$.

22 Budylin, S.L. Penalty Losses. Now in Russia? , Herald of Civil Law. Vol. 4. 2013
} 
punitive damages if the committed by him offense was aggravated by such circumstances as dishonesty, gross negligence or malice. ${ }^{23}$

A vivid example is the well-known case of Philip Morris USA v. Williams (1999 - 2011). It was acknowledged that the tobacco company conducted an unscrupulous advertising campaign aimed at creating a false impression of the relative safety of smoking. As a result, the jury decided that the company should pay the widow of the deceased from the cancer smoker not only the compensation damages of about 800 thousand dollars, but punitive damages of about 80 million dollars as well, excluding interest. Consequently, the punitive damages were 100 times higher than the amount of damage in the case. This verdict was appealed in courts of all instances and was repeatedly canceled, including the US Supreme Court, but then restored again. As a result, the verdict remained; it is still in effect after all exhausting possibilities of appeal. However, in this case, due to the Oregon state law, a significant part $(60 \%)$ of punitive damages was transferred to a special fund for crime victims, but not to the plaintiff. ${ }^{24}$ Notably, the grounds for awarding punitive damages in this case, as well as in other similar cases, was the behavior of the defendant, which the jury considered to be deserving a special punishment, but not just the violation of the plaintiff rights.

Primitive forms of punitive damages, actually in the form of multiple damages claims, can be observed in many historical legal systems, including the Laws of Hammurabi (Babylon, 1772 BC), the Laws of the Hittite Kingdom (Asia Minor, around 1400 BC), the Jewish Law of Moses (about 1200 BC), the Hindu Law of Manu (about 200 BC). ${ }^{25}$

Indeed, in the XIX century punitive damages were common practice in some German states, Prussia, for instance. ${ }^{26}$ However, the adoption of the Code of Napoleon in France (1804) and later the German Civil Code (1900), made a purely compensatory approach to tort law dominant in most countries of continental Europe. Therefore, the purpose of the defendant's payment was to compensate the inflicted damage, but not to punish the defendant. The functions

23 Afanasyeva, E.G., Dolgikh M.G. Private and Public in one Vial: penalty damages, Entrepreneurial law. Vol. 2. pp. $16-20.2009$

24 Philip Morris USA v. Williams, 549 U. S. 346 (2007); Green A. Oregon Supreme Court orders $\$ 99$ million award against Philip Morris // The Oregonian. 2011. Dec. 2 (доступно в Интернете по адресу: http://www. oregonlive. com/portland/index. ssf/2011/12/oregon_supreme_court_orders_99.html)

25 Owen, D. G. Punitive Damages in Product Liability Litigation, Michigan Law Review. 1976, pp. 1257, 1262 (note 17)

26 Georgiades, G. Punitive Damages in Europe and the USA: Doctrinal Differences and Practical Convergence, Revue Hellenique de Droit International. Vol. 58, 2005, pp. 145 - 163, 153 
of punishment became a part of public law, primarily criminal law. Currently, there are no punitive damages as a separate concept of tort law in the countries of the Romano-German legal family. Only special cases, if provided for by a special law, presuppose the possibility to recover from the defendant the amount of money in favor of the injured person above the inflicted damage. ${ }^{27}$

Punitive damages doctrine originated in Anglo-Saxon legal system. The countries of this legal family recognize the dual purpose of tort law: compensation to the victim and, in certain cases, punishment of the offender. The terms and rules for awarding punitive damages vary from jurisdiction to jurisdiction. ${ }^{28}$

The notion "punitive damages" in its modern sense evolved in England. ${ }^{29}$ For the first time the English court clearly formulated the doctrine of punitive damages in 1763 in the case of Huckle v. Money. ${ }^{30}$

In 1964, the applicability of punitive damages was significantly limited by the precedent of the House of Lords - the highest judicial body of the United Kingdom at that time (Rookes v. Barnard ${ }^{31}$ ). This strict limitation on punitive damages has not been recognized in many other common law jurisdictions, even those that used to follow the decisions of English courts: Canada, Australia, and New Zealand. ${ }^{32}$

In 1993, the Court of Appeal imposed additional restrictions on punitive damages (in $\mathrm{AB}$ v. South West Water case ${ }^{33}$ ). As a result, a number of delicts, including, careless injury, and fell into a group of delicts to which punitive damages are inapplicable. In Anglo-American law, a system of singular delicts is applied, i.e., liability is provided for certain types of delicts with specific actual corpus delicti. However, in 2001 the House of Lords in Kuddus v. Chief Constable of Leicestershire abolished this restriction. ${ }^{34}$ If the amount appoint-

\footnotetext{
27 Punitive damages in Europe: Concern, threat or non-issue? Swiss Re, 2012 (http://www. biztositasiszemle. hu/files/201206/punitive_damage_in_europe.pdf)

28 Gotanda, J.Y. Punitive Damages: A Comparative Analysis, Columbia Journal of Transnational Law. 2004. Vol. 42, p. 391 (Access at: http://papers. ssrn. com/sol3/papers. cfm? abstract_id=439884)

29 Gotanda, J. Y. Supplemental Damages in Private International Law, Kluwer Law International, The Hague 1998, pp. 198 - 199 (Access at: https://www.trans-lex.org/134000)

30 Huckle v. Money, (1763) 2 Wilson K. B. 205, 95 E. R. 768

31 Rookes v. Barnard, [1964] UKHL 1

32 Cunnington, R. Should Punitive damages be part of the judicial arsenal in contract cases? Legal Studies. Vol. 26. No. 3. pp. 369 - 393. 2006

33 AB v. South West Water Services Ltd., [1993] QB 507

34 Kuddus (AP) v. Chief Constable of Leicestershire Constabulary, [2001] UKHL 29
} 
ed by the jury is considered as "excessive", the Court of Appeal may appoint a new hearing of the case or individually reduce the amount of payment. ${ }^{35}$

Germany is considered a good example of a typical representative of the Romano-Germanic legal system. As has been mentioned above, the punitive damages are not in practice in Germany. The tort law of Germany (at least, if we analyze the relevant norms) implies the awarding of compensation relevant to the inflicted damage. Moreover, in 1992 the Supreme Court of Germany recognized that the punitive damages contradict the public order of Germany, and therefore the decisions of foreign courts providing for the imposition of punitive damages are not subject to recognition and enforcement in Germany. ${ }^{36}$ Nevertheless, there has been some evolution in the positions of the Supreme Court, an increasing willingness, in certain cases, to award a victim the compensation above the actually caused damage. Primarily, these are the cases of personal non-property rights violation, as there is no economic damage and the compensation is quite similar to Anglo-Saxon punitive damages. ${ }^{37}$ In 1973, this approach was completely supported by the Constitutional Court in the "case of the Iranian princess", which resulted in a great compensation to the ex-wife of the Shah of Iran for a published false interview with her. ${ }^{38}$

Theoretically, and it is interesting to note, that according to the Supreme Court, such a payment is not exactly the compensation for non-pecuniary damage. (Schmerzensgeld). ${ }^{39}$ The judicial decision of the Supreme Court was justified by the provisions of the first two articles of the Constitution (Basic Law) of Germany: the inviolability of human dignity and the right to free development of the individual, while preventing encroachment on the rights of others and on moral norms, but not the articles of the Civil law.

The Court believed that the absence of such a payment would mean the violation of honor and dignity of a person without any legal sanction, which is unacceptable. This Supreme Court's decision has much criticism of those jurists who believed it to be the violation of the fundamental principles of law. ${ }^{40}$

35 Courts and Legal Services Act 1990, art. I; John v. MGN Ltd., [1995] EWCA Civ. 23

36 Aufmkolk, H. U.S. Punitive Damages Awards before German Courts - Time for a New Approach, Frei - law - Freiburg Law Students Journal. Ausgabe VI. (Access at: http://www. freilaw. de/journal/eng/edition\%206/6_Aufmkolk\%20-\%20Punitive\%20Damages. pdf); BGH, 04.06.1992 - IX ZR 149/91, BGHZ 118, 312. 2007

37 BGH, 14.02.1958 - I ZR 151/56, BGHZ 26, 349

38 BVerfG, 14.02.1973 - 1 BvR 112/65, BVerfGE 34, 269

39 BGB, § 847 [1994]

40 Dannemann G. The German law of unjustified enrichment and restitution. Oxford University Press, 2009, pp. 91 - 96; Koziol H. Basic Questions of Tort Law from a Germanic Perspective. Jan Sramek Verlag, 2012, p. 39 
Obviously, the German courts are move away from the classic interpretation of losses as a purely compensative tool and recognize, to some extent, their functions of the "deterrence", which is more characteristic for public law sanctions, and Anglo-Saxon punitive damages. It is worth noting that some of the German regulations allow the possibility of awarding the plaintiff the compensation in excess of the caused harm, for instance, in case of gender discrimination of an employee. ${ }^{41}$

Punitive damages, to some extent, are of a mixed legal nature. On the one hand, they are of civil-legal basis, as they are awarded to the victim within the civil claim. Partly, the purpose of their appointment was traditionally the compensation of the plaintiff's suffering (it should be noted that historically the common law did not provide the possibility of compensation for moral harm, although the situation has changed over the past 100 years). In addition, the punitive damages are partly intended to compensate the plaintiff's efforts and costs, which sometimes require a lot, but which can be difficult to account for in compensatory damages, in the prosecution of the offender (It is a general rule for the United States, unlike the UK, not to compensate the litigation costs of the winning party). From the end of the XIX century, the English and American courts recognize the possibility of recovering compensation in the case of "deliberate causing of mental shock / serious emotional disorder". ${ }^{42}$ In case of an imprudent infliction of emotional disorder, such compensation has been appointed in the US since the late 1960s, but with serious reservations. ${ }^{43}$

On the other hand, punitive damages are of a public legal nature, since their main purpose is to punish the offender and prevent subsequent violations. It makes them similar to criminal sanctions (if exacted along with criminal sanctions, there might be the risk of "double punishment" for the same offense). Thus, it can be concluded that the plaintiff in such processes plays a part of a "private prosecutor", in fact defending not only his own, but also the public interests, for which he receives an additional reward in the form of a sum of punitive damages. ${ }^{44}$

\footnotetext{
$41 \quad$ Allgemeines Gleichbehandlungsgesetz, § 15 (Abs. 2)

42 Wilkinson v. Downton, [1897] 2 QB 57; Restatement (Second) of Torts, § 46)

43 Nolan, V.E., Ursin, E. Negligent Infliction of Emotional Distress: Coherence Emerging from Chaos, Hastings Law Journal. Vol. 33. 1982, p. 583

44 The Imposition of Punishment by Civil Courts: A Reappraisal of Punitive Damages // New York University Law Review. 1966. Vol. 41, pp.1158 - 1185
} 


\section{CONCLUSION: STRENGTHENING THE COMPENSATORY BASICS IN APPLICATION OF VIOLATED PROPRIETARY RIGHTS PROTECTION METHODS}

Under the legislation of continental legal system countries the implementation of vindication and negatory claims presupposes the claimant to be entitled to reckon upon the violator to exercise his rights aimed at returning illegally held property or removing obstacles to its use and the compensation for legal costs. ${ }^{45}$ When a vindication claim is presented, the plaintiff will demand a thing from someone else's unlawful possession. At that, the seizure is illegal in nature, though the consequence of the claim satisfaction is only the return of a lost property and the recovery of expenses for the fulfilment of the right to claim in a declarative procedure. A particular feature of the English law, the United States law and other countries of common law is the absence of vindication and negatory claims. In England, the property right is protected by separate types of claims from offenses, primarily by the claim of a violation of the immovable property ownership. This refers to the forcible acquisition of another's land plot, and simply the entrance to the fenced territory, to someone else's apartment or garden. Possession violations may concern movable things, including keeping them without the intention of turning into their property. Considering such claims, courts either seize things from violators, or prohibit their possession, or, finally, impose a fine on violators. ${ }^{46}$

Pursuing the objectives of litigation, the protection methods carry out, apart from a restorative function, a momentous preventive one, which essence is to reduce the level of subjective civil rights violation and, consequently, to reduce the number of claims, to ensure quick and efficient legal proceedings. In other words, a potential violator should be aware not only of the liability degree, which is reduced just to the return of a thing (vindication claim) in the proprietary relationship or to the elimination of an obstacle in its use (negatory claim), but of the risk of probable compensatory property losses that he will have to make in return for a violation.

The problem of the compensatory principle insufficiency is aggravated by the fact that the method of violated subjective civil rights protection is traditionally perceived in the Russian Federation law, exclusively, as a material and legal phenomenon, which, in turn, neutralizes its procedural and legal significance.

\footnotetext{
45 Faber, W., Lurger, B. National Reports on the Transfer of movables in Europe Volume 4: France Belgium, Bulgaria, Poland, Portugal. 2011. European law publishers GmbH, Munich. pp. 45 - 46

46 Zenin, I. A. Civil and Commercial Law of Foreign Countries: Textbook. Allowance, I. A. Zenin. - 2 nd ed., Moscow: Yurayt Publishing House; Higher Education, 2010.
} 
This leads to the fact that the court is restricted to the scope of the demand and is unable to impose additional compensatory (punitive) payments for the claimant or the state, taking into account the nature of the violation, the legal status of the subjects, as well as other worthy circumstances. At that, the decrease in the level of violations in private legal relations directly depends on possible adverse consequences for the offender, which imply not only a committing of a reverse action, but additional compensatory (punitive) losses that are imposed by the court and cannot be known in advance, so as not to become the incentive in the inclination to violate.

In order to accomplish the task, the mechanism to determine the additional compensations should be developed. It will ensure the equality of rights and interests of all participants in a protective legal relationship, the maximum and permissible amounts of compensatory payments, and the criteria for their establishment. This goal is topical and vital for all countries of the continental legal system, where Civil law is based on the reception of Roman law.

\section{LITERATURE:}

\section{BOOKS AND ARTICLES}

1. Arapov, N. T. Problems of the Theory and Practice of Justice in Civil Cases, Leningrad: Leningrad University Press, 1984

2. Abova, T. E. Protection of Economic Rights of Enterprises and Production Associations: Dis .... kand. ... Doct. Jurid. Sciences: M., 1985

3. Afanasyeva, E.G., Dolgikh M.G. Private and Public in one Vial: penalty damages, Entrepreneurial law. Vol. 2. pp. 16 - 20. 2009

4. Aufmkolk, H. U.S. Punitive Damages Awards before German Courts - Time for a New Approach, Frei - law - Freiburg Law Students Journal. Ausgabe VI. (Access at: http://www.freilaw.de/journal/eng/edition\%206/6_Aufmkolk\%20-\%20Punitive\%20Damages. pdf); BGH, 04.06.1992 - IX ZR 149/91, BGHZ 118, 312. 2007

5. Braginsky, M.I., Vitryansky, V.V. Contract Law. Book. The first. General Provisions. 3rd ed. M.: Statute. 2001

6. Budylin, S.L. Penalty Losses. Now in Russia? , Herald of Civil Law. Vol. 4. 2013

7. Cunnington, R. Should Punitive damages be part of the judicial arsenal in contract cases? Legal Studies. Vol. 26. No. 3. pp. 369 - 393. 2006

8. Faber, W., Lurger, B. National Reports on the Transfer of movables in Europe Volume 4: France Belgium, Bulgaria, Poland, Portugal. European law publishers GmbH, Munich. 2011 
9. Georgiades, G. Punitive Damages in Europe and the USA: Doctrinal Differences and Practical Convergence, Revue Hellenique de Droit International. Vol. 58, 2005

10. Gotanda, J.Y. Punitive Damages: A Comparative Analysis, Columbia Journal of Transnational Law. 2004. Vol. 42 (Access at: http://papers.ssrn.com/sol3/papers. cfm? abstract_id=439884)

11. Gotanda, J. Y. Supplemental Damages in Private International Law, Kluwer Law International, The Hague 1998. (Access at: https://www.trans-lex.org/134000)

12. Dannemann, G. The German law of unjustified enrichment and restitution. Oxford University Press, 2009.

13. Degenkolb, Heinrich. Einlassungszwang und Urteilsnorm. Leipzig, 1879, Beitrage zum Zivilprozess. Leipzig. 1905

14. Hasse, J.C. Ueber das Wesen der action, Reinisches Museum fur Jurisprudenz. Bd. 1833

15. The Imposition of Punishment by Civil Courts: A Reappraisal of Punitive Damages, New York University Law Review. Vol. 41. pp. 1158 - 1185, 1966

16. Koziol, H. Basic Questions of Tort Law from a Germanic Perspective. Jan Sramek Verlag, 2012

17. Kravchenko. A. A. On the issue of the concept of a method of protecting civil rights, Advocate. 2014. Vol. 7. pp. 22 - 30

18. Kroll, Wilhelm. Klage und Einrede nach Deutschem Recht: auf Grundlage der Reichsgesetze unter Berucksichtingung des gemeinen Rechtes und der wichtigsten Partikularrechte dargestellt. Berlin, 1884

19. Kurbatov, A. Ya. Problems of the application of legislation on the protection of consumer rights in the banking sector, created by judicial-arbitration practice. Entrepreneurship. Application Business and Law in Russia and Abroad. Vol. 3. pp. $36-39,2013$

20. Mattei, Ugo. Basic principles of property law: A comparative Legal and Economic Introduction. By Greenwood Press. 2000

21. Morgunov, S. V. Vindication in civil law. Theory. Problems. Practice. Moscow: Statute, 2006

22. Nolan, V. E., Ursin, E. Negligent Infliction of Emotional Distress: Coherence Emerging from Chaos, Hastings Law Journal. Vol. 33. 1982

23. Owen, D. G. Punitive Damages in Product Liability Litigation, Michigan Law Review. 1976

24. Radaeva, O. I. Problems of judicial protection of property rights and the right of common ownership, The Russian judge. Vol.1. p. 20. 2013 
25. Romanchuk, S. V. Traditions and innovations in determining the right to judicial protection of subjective civil rights and legally protected interests. Development of world justice in modern conditions: problems and prospects, dedicated to the 70th anniversary of the formation of the judicial system of the Tyumen region. Proceedings of the Conference of Justices of the Peace in the Tyumen region. Tyumen: Tyumen Regional Court, pp. 29 - 31. 2014

26. F. K. v. Savigny. System des heutigen römischen Rechts. Berlin, Veit und comp.1841, Bd. V.

27. Semenov, V. V. Vindication: theory and jurisprudence, Russian Justice. Vol. 2. pp. $8-10.2016$

28. Zgonnikov, P. P. On some topical issues of civil rights protection, Russian Justice. 2016. № 4. pp. 9 - 12

29. Zenin, I. A. Civil and Commercial Law of Foreign Countries: Textbook. Allowance, I. A. Zenin. - 2 nd ed., Moscow: Yurayt Publishing House; Higher Education, 2010

30. Wach, Adolf. Handbuch des deutschen Civil prozessrecht. Leipzig, Verlag von Dunkers \&Humbolt.1885, Bd. I

\section{LEGISLATION}

1. European Convention for the Protection of Human Rights and Fundamental Freedoms, Rome, November 4, 1950

2. Treaty Establishing the European Economic Community and related instruments, Rome, March 25, 1957.

3. Code de procédure civile (France), 1975

4. Courts and Legal Services Act 1990, art. I; John v. MGN Ltd., [1995] EWCA Civ. 23

5. Civil Procedure Code (Germany) as promulgated on 5 December 2005 (Bundesgesetzblatt (BGBl).

6. Arbitration Procedure Code of the Russian Federation of July 24, 2002 N 95-FZ (as amended on June 23, 2016), Collected Legislation of the Russian Federation. № 30. Art. 3012. 2002

7. Civil Procedure Code of the Russian Federation No. 138-Ф3 of 14.11.2002 (as amended on 03.07.2016), Meeting of the legislation of the Russian Federation. № 46. Art. 4532. 2002

8. Federal Law No. 68-FL of 30 April 2010 "On Compensation for Violation of the Right to Proceed in Due Process within a Reasonable Time or the Right to Enforce a Judicial Act within a Reasonable Time" (as amended on 19.12.2016), Collection of Legislation of the Russian Federation. № 18. Art. 2144. 2010 
9. Administrative Procedure Code of the Russian Federation of 08.03.2015 No. 21Fl (as amended on 03.07.2016), Collection of Legislation of the Russian Federation. № 10. Art. 1391. 2015

10. Decree of the President of the Russian Federation of July 18, 2008, No. 1108 (amended on July 29, 2014) "On the Improvement of the Civil Code of the Russian Federation”, Collection of Legislation of the Russian Federation. № 29 (Part 1), art. 3482. 2008

\section{WEB SOURCES}

1. https://www.trans-lex.org, last accessed on 15/05/2017.

2. http://themecraft.net/www/biztositasiszemle.hu last accessed on 12/05/2017.

\section{JUDICIAL PRACTICE}

1. Philip Morris USA v. Williams, 549 U. S. 346 (2007); Green A. Oregon Supreme Court orders $\$ 99$ million award against Philip Morris // The Oregonian. 2011. Dec. 2 (доступно в Интернете по адресу: http:/www. oregonlive. com/portland/index.ssf/2011/12/oregon_supreme_court_orders_99.html)

2. Huckle v. Money, (1763) 2 Wilson K. B. 205, 95 E. R. 768

3. Punitive damages in Europe: Concern, threat or non-issue? Swiss Re, 2012 (http:// www. biztositasiszemle.hu/files/201206/punitive_damage_in_europe.pdf)

4. Rookes v. Barnard, [1964] UKHL 1

5. AB v. South West Water Services Ltd., [1993] QB 507

6. Kuddus (AP) v. Chief Constable of Leicestershire Constabulary, [2001] UKHL 29

7. Wilkinson v. Downton, [1897] 2 QB 57; Restatement (Second) of Torts, § 46) 